\title{
The Use of a Graphite-Silicone Rubber Composite Electrode in the Determination of Rutin in Pharmaceutical Formulation
}

\author{
Sidney X. dos Santos, Luiz H. Mazo and Éder T. G. Cavalheiro* \\ Instituto de Química de São Carlos, Universidade de São Paulo, Av. Trabalhador Sãocarlense, 400, \\ CP 676, 13560-970 São Carlos-SP, Brazil
}

\begin{abstract}
O uso de um eletrodo compósito à base de grafite de borracha de silicone (GSR) na determinação de rutina, (vitamina $\mathrm{P}$ ), por voltametria de pulso diferencial, é descrito. Voltamogramas cíclicos da rutina apresentaram um par de picos de oxidação/redução no GSR em 0,411 e 0,390 V (vs. ECS), respectivamente, em solução tampão Britton-Robinson (B-R) pH 4,0. Em voltametria de pulso diferencial (DPV), após a otimização das condições, o pico de oxidação em $0,370 \mathrm{~V}$ (vs. ECS) foi usado na determinação quantitativa de rutina. Neste caso, um intervalo linear entre $5,0-50,0 \times 10^{-8} \mathrm{~mol} \mathrm{~L}^{-1}$ foi observado com um limite de detecção de $1,8 \times 10^{-8} \mathrm{~mol} \mathrm{~L}^{-1}$. Recuperações de 94 a $113 \%$ foram observadas. A superfície do eletrodo foi renovada por polimento, com uma repetibilidade de $1,09 \pm 0,06 \mu \mathrm{A}(\mathrm{n}=10)$ para a corrente de pico. A rutina foi determinada em uma formulação farmacêutica e os resultados concordaram com aqueles obtidos de um método oficial com $95 \%$ de confiança.
\end{abstract}

The possibility of using a graphite silicone-rubber composite electrode (GSR) in a differential pulse voltammetric(DPV) procedure for rutin (vitamin P) determination is described. Cyclic voltammograms of rutin presented a reversible pair of oxidation/reduction peaks respectively at 0.411 and $0.390 \mathrm{~V}$ ( vs. SCE) at the GSR surface in Britton-Robinson(B-R) buffer solution pH 4.0. In DPV after optimization of conditions, an oxidation peak at $0.370 \mathrm{~V}$ (vs. SCE) was used to quantitative determination of rutin in B-R buffer solution $\mathrm{pH}$ 4.0. In this case a linear dynamic range of $5.0 \times 10^{-8}$ to $50.0 \times 10^{-8} \mathrm{~mol} \mathrm{~L}^{-1}$ was observed with a detection limit of $1.8 \times 10^{-8} \mathrm{~mol} \mathrm{~L}^{-1}$ for the analyte. Recoveries from 94 to $113 \%$ were observed. The electrode surface was renewed by polishing after each determination, with a repeatability of $1.09 \pm 0.06 \mu \mathrm{A}(\mathrm{n}=10)$ peak current. Rutin was determined in a pharmaceutical formulation using the proposed electrode and the results agreed with those from an official method within $95 \%$ confidence level.

Keywords: composite electrode material, graphite, silicone rubber, rutin

\section{Introduction}

The use of carbon based electrodes became very popular in electroanalysis due to its satisfactory response in the positive potential range, in which the mercury does not present an adequate behavior. Carbon electrodes can be used in the study of organic and inorganic substances, in both oxidation and reduction processes. The highest success is obtained when applied in investigations in the oxidative reactions, due to its wide range of anodic polarization with low residual currents. ${ }^{1}$

The literature presents several kinds of carbon based electrodes, being classical examples the pyrolytic graphite, ${ }^{2}$ glassy carbon $(\mathrm{GC})^{3}$ and carbon fiber ${ }^{4}$ electrodes besides

*e-mail: cavalheiro@iqsc.usp.br the composite materials prepared with several organic or polymeric solvents as binders. ${ }^{5}$

According to Tallman and Petersen, a composite electrode can be defined as "a material consisting of at least one conductor phase commingled with at least one insulator phase". ${ }^{6}$

The advantages of the composite electrodes are the relative easiness of preparation and surface renewing, possibility of modifier incorporation and relative repeatability of effective area. ${ }^{7}$

Among these composite materials, one can stand out the graphite silicone-rubber electrode (GSR), a polymeric material that was first described by Pungor and Szepesváry ${ }^{1}$ and recently retaken by our group. ${ }^{8}$ In these materials, the polymeric phase of the composite checks viscosity to the mixture before the cure, when 
the composite can be moulded in different shapes and sizes. After curing of the polymeric phase, the composite presents mechanical resistance, besides stability in non-aqueous solvents and capability for flow analysis applications. ${ }^{9}$

Flavonoids represent a large family of polyphenolic compounds widely present in plants ${ }^{10}$ that have been demonstrated to be important factors for color, taste, arome and stability of many plant-based food or beverages. ${ }^{11}$ They naturally occur in fruits, vegetables, nuts, seeds, flowers, and bark. They also have been reported to exhibit a wide range of biological effects, including antibacterial, antiviral, anti-inflammatory, anti-allergic, and vasodilator actions. In addition, flavonoids inhibit lipid peroxidation platelet aggregation, capillary permeability, and fragility, and the activity of enzyme systems including cyclo-oxygenase and lipoxygenase. ${ }^{12}$

Rutin, 3',4',5,7-tetrahydroxyflavone-3 $\beta$-D-rutinoside, is a glucoside flavonoid very common in the alimentary diet and also known as vitamin P. ${ }^{13}$ Rutin presents the capability to increase the strength of the capillary blood vessels and to improve the permeability, being essential for a better absorption of vitamin $\mathrm{C}$ in the organism. ${ }^{13}$ This flavonoid has been applied to treat high blood pressure and vascular fragility and related diseases. ${ }^{14}$ The rutin chemical structure is presented in Scheme 1.

The literature presents many reports regarding the determination of rutin using electroanalytical procedures. Using a GC electrode Ghica and Brett performed an investigation of electrochemical behavior of rutin, in which an oxidation mechanism is proposed..$^{10}$ Kang et al. ${ }^{14}$ quantified rutin using DPV in several samples of chinese medicines. Hua et al. ${ }^{15}$ studied the electrochemical behavior by square wave stripping voltammetry and applied in determination of rutin in tablets.

Malagutti et al. ${ }^{16}$ reported a comparative study of rutin at a GC electrode and a rigid graphite-polyurethane composite electrode. A procedure based on square wave voltammetry (SWV) was developed and applied in the determination of rutin in tea infusion samples.

Examples of the use of carbon paste electrodes are the works of Volikakis and Efstathiou that used adsorptive stripping voltammetry to determine twelve flavonoids in a flow injection system ${ }^{17}$ and Zoulis et al. ${ }^{18}$ that studied the preconcentration of rutin and other flavonoids in carbon paste and carried out its determination by adsorptive stripping voltammetry.

Some papers described the use of modified carbon based electrodes. Examples are those presented by Yongxia et al. ${ }^{19}$ that used carbon nanotubes to modify the GC surface and studied rutin electrochemical behavior by cyclic voltammetry (CV) and SWV in details. Santos et al. ${ }^{20}$ deposited a film of poly glutamic acid in a GC electrode and determined rutin by SWV in pharmaceutical formulation.

He et al. ${ }^{21}$ modified a GC electrode with multi-wall carbon nanotubes (MWCNT)- $\beta$-cyclodextrin film. The electrochemical behavior of rutin at a chemically modified electrode was investigated by CV. This sensor was used for the determination of rutin in urine samples. Franzoi et al. ${ }^{22}$ modified a carbon paste electrode with poly(vinylpyrrolidine) and evaluated the effect of several parameters in the performance of the modified electrode. Such device was successfully applied to the determination of rutin in pharmaceutical formulation.

In this work we report the use of a GSR 70\% (graphite, $\mathrm{m} / \mathrm{m}$ ) for the voltammetric determination of rutin in pharmaceutical formulation. Such electrode was used considering the easiness of preparation, low cost, high stability, long life and reproducible response between successive surface renovations, since rutin strongly adsorbs at the carbon surface.

\section{Experimental}

\section{Reagents and solutions}

All reagents were of analytical grade and used as received. Solutions were prepared with water treated in a Milli-Q system (Millipore).

Rutin was purchased from Natural Pharma (Brazil). Britton-Robinson (B-R) buffer solutions at various $\mathrm{pH}$ values were used as supporting electrolytes.

With the aid of ultrasonic agitation, stock solution of rutin were prepared daily at a $0.50 \mathrm{mmol} \mathrm{L}^{-1}$ concentration in ethanol, and kept at $4{ }^{\circ} \mathrm{C}$ in a refrigerator. These solutions were diluted to the desired concentrations with the buffer solutions.

\section{Apparatus}

Voltammetric experiments were performed using a BAS-CV 50W potentiostat (Bionalytical Systems, USA) coupled to a personal computer and controlled with BAS 2.3 software. A three-electrode cell, with $25.0 \mathrm{~mL}$ total capacity, was used with a saturated calomel electrode (SCE) and a platinum wire (1 $\mathrm{cm}$ longer) as the reference and counter electrodes, respectively. The $70 \%$ (graphite, $\mathrm{m} / \mathrm{m}$ ) composite $^{8}$ and a GC were used as working electrodes for comparison. All measurements were performed at room temperature. 


\section{Preparation of the composite electrodes}

The electrodes were prepared by mixing adequate amounts of graphite powder and silicone-rubber in a glass mortar for $10 \mathrm{~min}$, in order to obtain a mixture with $70 \%$ of graphite $(\mathrm{m} / \mathrm{m})$. The resulting mixture was inserted in a glass tube $(\phi 3.0 \mathrm{~mm})$ and with the aid of a copper wire $(\phi 3.0 \mathrm{~mm})$ it was compressed in a hydraulic press for $24 \mathrm{~h}$. After curing, the electric contact was established connecting the copper wire $(\phi 3.0 \mathrm{~mm})$ to the composite with the help of a silver epoxy (EPO-TEK 410E, Epoxy Technology, USA).

\section{Procedures}

The voltammetric experiments for rutin determination were performed after dearation with $\mathrm{N}_{2}$ bubbled for 10 min. The electrode surface was renewed between each measurement by polishing in 600 grit sand paper followed by a soft cloth in an APL-2 (Arotec, Brasil) polishing wheel.

\section{Procedures for pharmaceutical formulation analysis}

According to the Brazilian Pharmacopeia, ${ }^{23}$ twenty tablets of Novarrutina ${ }^{\circledR}$ were weighed accurately up to $\pm 0.1 \mathrm{mg}$. The tablets were powdered in a glass mortar and a portion equivalent to $40 \mathrm{mg}$ of rutin, according to the label, was dissolved in $25.0 \mathrm{~mL}$ of ethanol. An aliquot of this solution was diluted in $25.0 \mathrm{~mL}$ of B-R buffer $\mathrm{pH} 4.0$ to prepare a sample solution.

An appropriate aliquot of this sample solution was then diluted directly in the cell in order to reach a final $2.0 \times$ $10^{-7} \mathrm{~mol} \mathrm{~L}^{-1}$ rutin concentration.

To this solution three $150 \mu \mathrm{L}$ aliquots of rutin standard solution, $1.0 \times 10^{-5} \mathrm{~mol} \mathrm{~L}^{-1}$, was added successively. After each addition three differential pulse voltammograms were taken between $100-600 \mathrm{mV}\left(v s\right.$. SCE) at $10 \mathrm{mV} \mathrm{s}^{-1}$ scan rate.

\section{Comparison method}

For comparison it was used the official method described in the AOAC Official Methods, ${ }^{24}$ that consists of a spectrophotometric procedure based in the measurement of the sample solutions absorbance at 338.5, 352.5 and $366.5 \mathrm{~nm}$ wavelengths using water as a blank.

The standard solution was prepared by dissolving $100 \mathrm{mg}$ of rutin in $250 \mathrm{~mL}$ of a solution of ethanol and acetic acid $0.9 \mathrm{~mol} \mathrm{~L}^{-1}(11: 1, \mathrm{v} / \mathrm{v})$. An aliquot of $5 \mathrm{~mL}$ of this solution was diluted to $100 \mathrm{~mL}$ in water to obtain a standard solution of $0.02 \mathrm{mg} \mathrm{mL}^{-1}$. In this case, the sample solution was prepared weighing a tablet amount equivalent to a rutin mass between 0.05 and $0.5 \mathrm{~g}$ and dissolving in solution of ethanol and acetic acid $0.9 \mathrm{~mol} \mathrm{~L}^{-1}(11: 1, \mathrm{v} / \mathrm{v})$, resulting in an approximately $0.02 \mathrm{mg} \mathrm{mL}^{-1}$ solution.

\section{Results and Discussion}

According to the previously described $\mathrm{CV}$ and scanning electron micrography results ${ }^{8}$ using composites containing between 30 and $70 \%$ of graphite $(\mathrm{m} / \mathrm{m})$, it was the $70 \%$ (graphite, $\mathrm{m} / \mathrm{m}$ ) the composition that presented the best electroanalytical response, thus it was used in the present work.

\section{Cyclic voltammetry}

The oxidation reaction of flavonoids is strongly related to their structure, which contains several free phenolic hydroxyl groups, particularly $o$-phenolic ones. ${ }^{10}$ In the case of rutin, the reversible redox process can be represented by the chemical reaction, represented in Scheme $1 .{ }^{10}$

According to the cyclic voltammograms of rutin in B-R buffer solution (Figure 1), at pH 4.0 and scan rate $50 \mathrm{mV} \mathrm{s}^{-1}$, there was only one pair of oxidation-reduction peaks when the potential is scanned from 0.0 to $0.6 \mathrm{~V}$. Under these conditions the oxidation and reduction peak potentials of rutin were, respectively, 0.411 and $0.390 \mathrm{~V}$ (vs. SCE), which corresponded to the oxidation of the 3',4'-dihydroxy substituent on the B-ring of rutin and the reduction of the corresponding 3,4-diquinone respectively. ${ }^{10}$

The GSR presented a better peak definition and higher current signal when compared with the GC as presented in Figure 1.

The small difference in the background currents between GC and GSR can be related to an adsorption of the analyte on the composite electrode. The adsorption was investigated by observing the dependence of peak potentials and currents as a function of the scan rate.

The peak potentials in both anodic and cathodic sweeps as weel as the $\Delta \mathrm{E}_{\mathrm{p}} \approx 21 \mathrm{mV}$ are practically independent of the scan rate, suggesting that the redox process is controlled by adsorption (Figure 2). ${ }^{25}$

However the peak currents (anodic and cathodic) change linearly with the scan rate only for $v>50 \mathrm{mV} \mathrm{s}^{-1}$ as presented in Figure 3a. This is not expected for a totally adsorption controlled process. ${ }^{25}$ On the other hand it is linearly dependent on the square-root of scan rate (Figure $3 \mathrm{~b}$ ), suggesting that the process is controlled also by diffusion at lower scan rates as discussed by Brown and Large. ${ }^{26}$ 


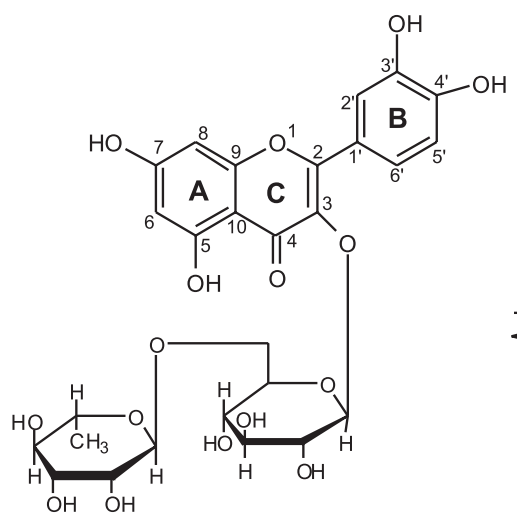

Rutin

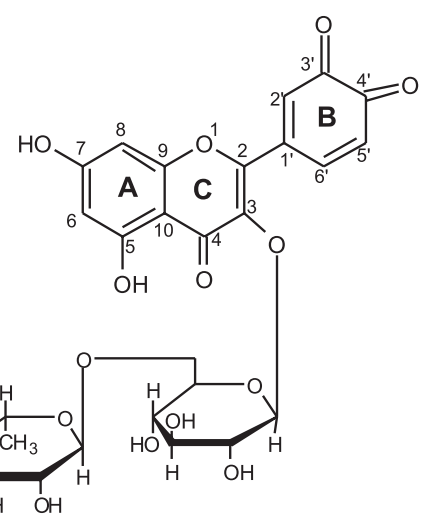

Oxidation product

Scheme 1.

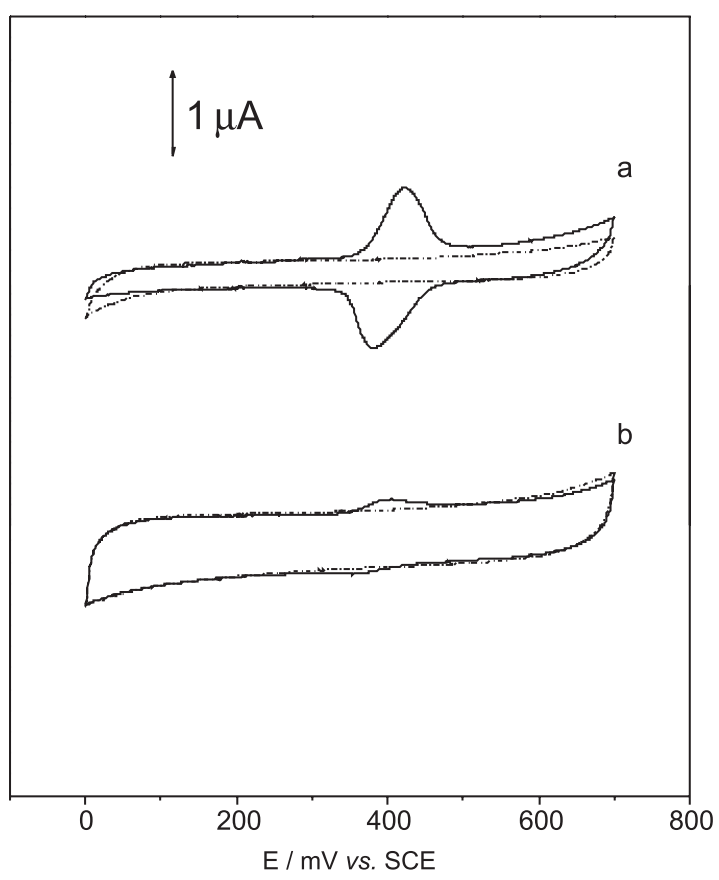

Figure 1. Cyclic voltammograms obtained with (a) the GSR and (b) GC electrodes in B-R buffer $\mathrm{pH}$ 4.0. (-) containing $5.0 \times 10^{-6} \mathrm{~mol} \mathrm{~L}^{-1}$ rutin (---) without rutin. Scan rate $50 \mathrm{mV} \mathrm{s}^{-1}$.

Zheng et al. ${ }^{27}$ observed a totally adsorption control during the all scan rate range, but using a single wall carbon nanotube modified gold electrode.

If the potential sweep is extended up to $1.2 \mathrm{~V}$, an additional irreversible oxidation process is observed at $1.0 \mathrm{~V}$ (vs. SCE). According to Ghica and Brett, this is related to the oxidation of the $-\mathrm{OH}$ groups in the A ring of rutin. ${ }^{10}$

\section{Effect of $\mathrm{pH}$ on the voltammograms}

The anodic and cathodic peak potential changes to more negative values when the $\mathrm{pH}$ varies from 2 to 6 . The

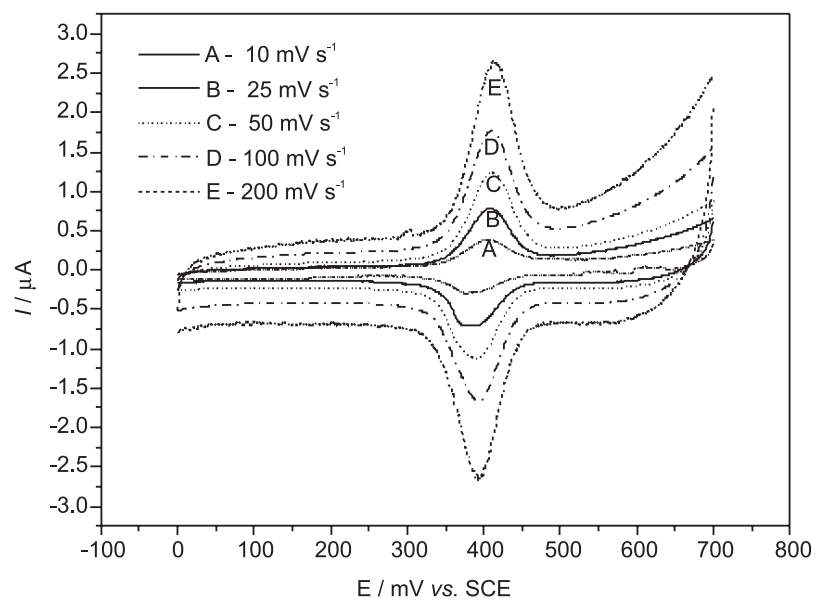

Figure 2. Cyclic voltammograms of $5.0 \times 10^{-6} \mathrm{~mol} \mathrm{~L}^{-1}$ at GSR rutin in B-R buffer $\mathrm{pH} 4.0$ at different scan rates (from inner to outer): 10, 25, 50,100 and $200 \mathrm{mV} \mathrm{s}^{-1}$.

respective peak current diminishes as the $\mathrm{pH}$ increases. Under the conditions used in this work, above $\mathrm{pH} 6$ no peaks were observed in the cyclic voltammograms (Figure 4a).

A linear dependence of peak potential is observed as presented in Figure $4 \mathrm{~b}$, and obeyed the following relationships:

$\mathrm{E}_{\mathrm{pa}}(\mathrm{mV})=649 \mathrm{mV}-61 \mathrm{pH}(\mathrm{r}=0.999), \mathrm{n}=4$

$\mathrm{E}_{\mathrm{pc}}(\mathrm{mV})=604 \mathrm{mV}-56.4 \mathrm{pH}(\mathrm{r}=0.998), \mathrm{n}=4$

The slopes of these equations, close to $59 \mathrm{mV}$ suggest that the same number of protons and electrons are involved in the redox process. According to many authors, ${ }^{10,27,28}$ in this case, 2 protons and 2 electrons are involved.

Zeng et al. ${ }^{27}$ suggested that at higher $\mathrm{pH}$ medium the electrochemical reaction became more difficult due to the shortage of proton. 

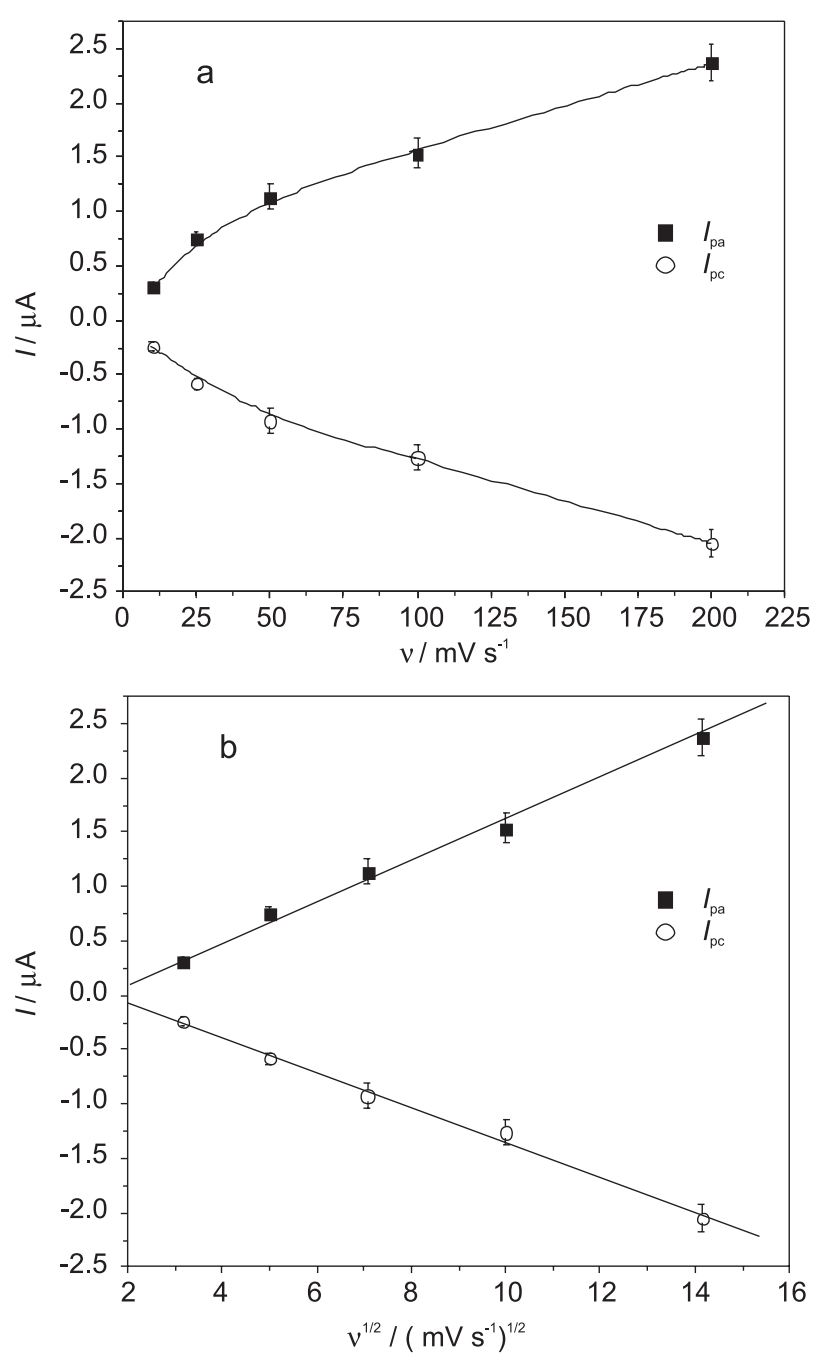

Figure 3. Dependence of anodic and cathodic peak currents with scan rate (a) and square-root of scan rate (b).

The potential shift per $\mathrm{pH}$ unit is about $-0.06 \mathrm{~V}$, which is similar to the behavior of anthraquinones, ${ }^{14}$ and is reasonable for the expected 2-electron/2-proton oxidation of the cathecol 3',4'-dihydroxyl group in the rutin molecule to the quinone form. ${ }^{14,29}$

DPV measurements and optimization of the composite electrode response

Optimal conditions for rutin determination using DPV were first established. The effect of scan rate $\left(10-100 \mathrm{mV} \mathrm{s}^{-1}\right)$ and pulse amplitude $(10-100 \mathrm{mV})$ were first evaluated being $10 \mathrm{mV} \mathrm{s}^{-1}$ and $50 \mathrm{mV}$ the best parameters. Although higher peak currents were observed in $\mathrm{pH} 2.0$ this was not chosen for analytical purposes since a relative higher standard deviation in successive measurements was noted (see insert in Figure 4a). The pH 4.0 was chosen once the results were more reproducible.
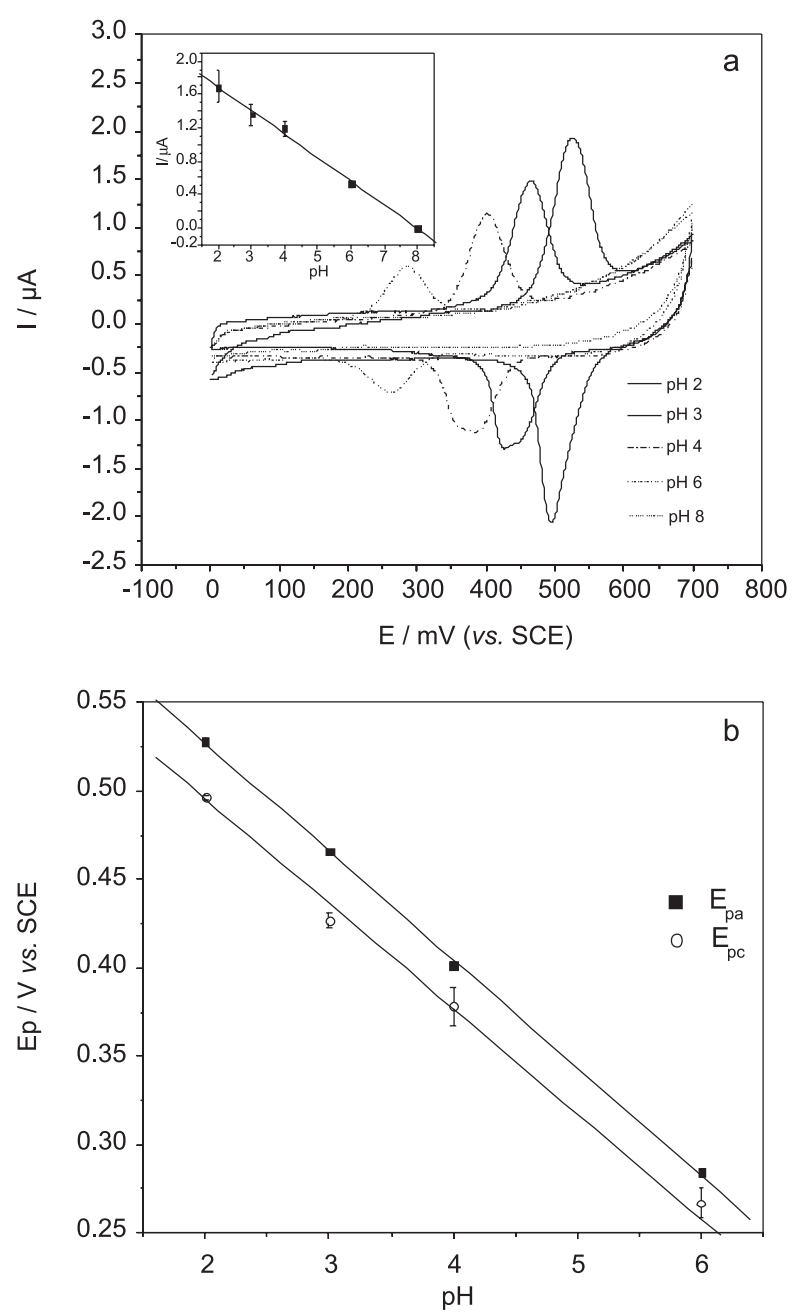

Figure 4. (a) Influence of supporting electrolyte $\mathrm{pH}$ on current response of $5.0 \times 10^{-6} \mathrm{~mol} \mathrm{~L}^{-1}$ rutin. Scan rate $50 \mathrm{mV} \mathrm{s}^{-1}$. Insertion show the dependence of anodic peak current with $\mathrm{pH}$ (b) peak potential dependence on $\mathrm{pH}$ for (ם) anodic peak potential ( $\square$ ) cathodic peak potential.

After optimization of the DPV experimental conditions at the GSR, voltammetric measurements were accomplished in B-R buffer solution $\mathrm{pH} 4.0$ in different rutin concentrations to obtain an analytical curve for the determination of the linear range for this system. The voltammetric response was linear from 0.050 to $0.50 \mu \mathrm{mol} \mathrm{L}{ }^{-1}(n=7)$, at $0.370 \mathrm{~V}$ (vs. $\mathrm{SCE})$ potential peak obeying the following equation:

$$
\begin{array}{r}
\text { Ip }=-3.54 \times 10^{-9} \mathrm{~A}+0.2855 \mathrm{~A} \mathrm{~mol}^{-1} \mathrm{~L} \times \mathrm{C}_{\text {Rutin }}, \\
(\mathrm{r}=0.9945, \mathrm{n}=7)
\end{array}
$$

in which Ip is the peak current (A) and $\mathrm{C}_{\text {Rutin }}$ is the total rutin concentration $\left(\mathrm{mol} \mathrm{L}^{-1}\right)$. The analytical curve was obtained measuring the peak currents for three successive DPV runs at each concentration. From these data a $17.64 \mathrm{nmol} \mathrm{L}^{-1}$ detection limit was determined for rutin.

Analytical curves (Figure 5) were also obtained at a $\mathrm{GC}$ electrode for comparison. At the GC a linear dynamic 


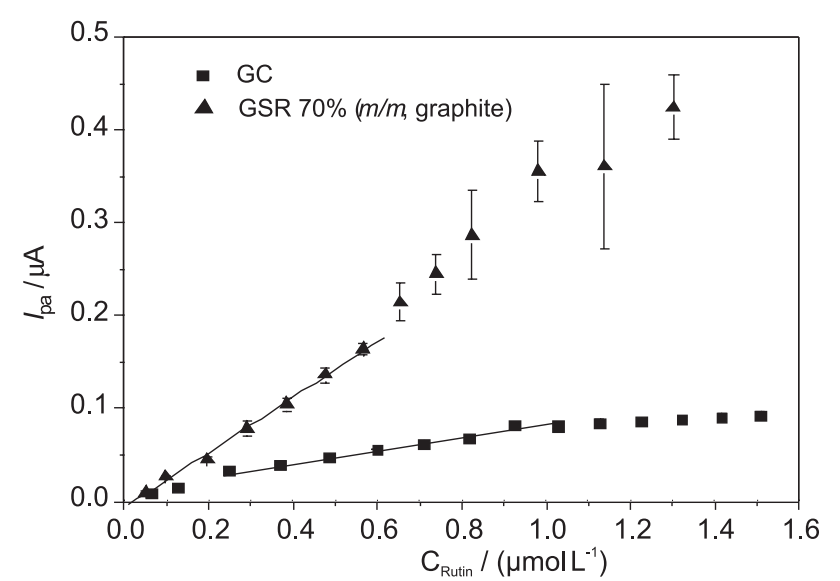

Figure 5. Analytical curves obtained for GSR and GC electrodes in B-R buffer $\mathrm{pH} 4.0$. Scan rate $10 \mathrm{mV} \mathrm{s}^{-1}$ and pulse amplitude $50 \mathrm{mV}$.

range between 0.24 to $0.82 \mu \mathrm{mol} \mathrm{\textrm {L } ^ { - 1 }}$ was observed with a slope of $0.0616 \mathrm{~A} \mathrm{~mol}^{-1} \mathrm{~L}$ which is markedly lower than that observed for the GSR as in equation 3, the limit of detection (LOD) obtained was $47.7 \mathrm{nmol} \mathrm{L}{ }^{-1}$. In Figure 5 , the analytical curves obtained for both GSR and glassy carbon are presented. A second linear range was observed for the GSR between $0.56-0.98 \mu \mathrm{mol} \mathrm{L} \mathrm{L}^{-1}$.

The presence of a shorter second linear dynamic range, has been attributed to an adsorption of the analyte on the electrode surface, that becames evident at higher concentration, that increases the sensitivity. Above $1.0 \mu \mathrm{mol} \mathrm{L} \mathrm{L}^{-1}$ a typical saturation of the electrode active takes place as presented in Figure 5.

In the case of the GC the saturation also occurs above $1 \mu \mathrm{mol} \mathrm{L}{ }^{-1}$, with only one linear range.

The GSR electrode was submitted to 10 successive determinations of rutin using a $5.0 \times 10^{-6} \mathrm{~mol} \mathrm{~L}^{-1}$ in B-R buffer $\mathrm{pH} 4.0$ solution in order to evaluate the repeatability of the measurements. The electrode surface was renewed after each determination, resulting in a mean peak current of $1.09 \pm 0.06 \mu \mathrm{A}(\mathrm{n}=10)$.

Apparently the standard deviation within the analytical curve is lower than that observed outside the linear range. To evaluate this, three successive determinations of 0.476 and $1.303 \mu \mathrm{mol} \mathrm{L}{ }^{-1}$ were taken after surface renewing. The peak currents at these concentrations were $0.136 \pm 0.008$ and $0.42 \pm 0.03 \mu \mathrm{A}$, respectively. Thus we concluded that the repeatability is not affected significantly by the amount of analyte in solution, since the standard deviation is in the order of $5-7 \%$ in or outside the linear region.

\section{Determination in pharmaceutical formulation}

Finally the performance of the proposed method in the determination of rutin in pharmaceutical formulations

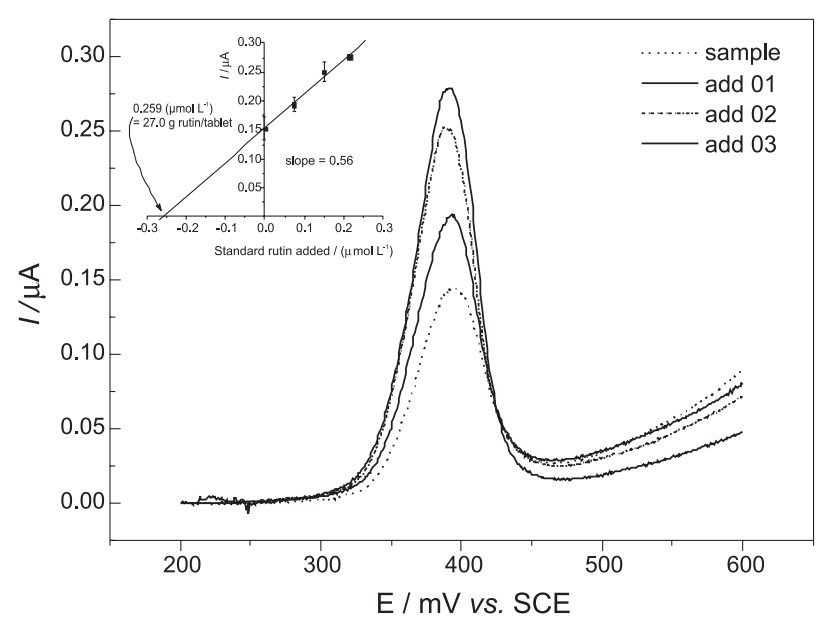

Figure 6. Standard addition curves for rutin determination in tablets Novarrutina ${ }^{\circledast}$. B-R buffer $\mathrm{pH}$ 4.0. Scan rate $10 \mathrm{mV} \mathrm{s}^{-1}$ and pulse amplitude $50 \mathrm{mV}$. The sample was prepared to be $\pm 2.0 \times 10^{-7} \mathrm{~mol} \mathrm{~L}^{-1}$ in rutin according to the lable. In each addition $7.3 \times 10^{-8} \mathrm{~mol} \mathrm{~L}^{-1}$ rutin was added.

Table 1. Determination of rutin in three aliquots of the pharmaceutical formulations Novarrutina ${ }^{\circledR}$ using the $70 \%$ (graphite, $\mathrm{m} / \mathrm{m}$ ) composite electrode and spectrophotometric method

\begin{tabular}{lccc}
\hline \multirow{2}{*}{ Sample $^{\mathrm{a}}$} & \multicolumn{2}{c}{ Rutin (mg/tablet) } & Relative error $/(\%)^{\mathrm{b}}$ \\
\cline { 2 - 3 } & DPV & Spectrophotometric & \\
\hline 1 & 28.0 & 27.0 & 3.7 \\
2 & 28.2 & 27.0 & 4.4 \\
3 & 27.0 & 27.0 & 0 \\
\hline
\end{tabular}

${ }^{a}$ Labeled value: $20 \mathrm{mg} /$ tablet. ${ }^{b} \mid$ Relative error $\mid=[(\mathrm{DPV}-$ Spectrophotometric $) /$ Spectrophotometric $\times 100 \%]$.

was evaluated. For the voltammetric determination of the rutin in tablets, the standard addition method was used (Figure 6).

The results obtained by DPV were compared to those obtained by official method and were presented in Table 1 . The DPV results agreed with those from the spectrophotometric procedure within $95 \%$ of confidence level.

The agreement between results from the two methods leads to conclude that there are more rutin in the samples than stated in the label. Considering that the pharmaceutical product is a natural extract is not at all a surprise the relatively higher rutin amount found by both the proposed and the official methods.

Recovery tests were also performed resulting in a mean recovery of 93.7 to $113.0 \%$ using the proposed procedure.

\section{Conclusions}

According to the results obtained in this work, the GSR represented a promising alternative as an electrodic material 
in the determination of flavonoids. The GSR presented higher sensitivity when compared with GC and other electrodes presented earlier, easy preparation, low cost, long useful life and easy surface renewal. The electrode is quite stable and has been used for more than 1 year in our laboratory.

The proposed method could be successfully applied to the determination of rutin in pharmaceutical formulations, providing results that were comparable with those obtained from the official spectrophotometric method. It requires renewal of the electrode surface due to the adsorption of the analyte, however reasonable repeatability could be obtained.

The performance of the GSR electrode proposed in this work is better than those observed for the GC. When compared to other electrodes described in literature, the LOD is much lower to the CNT sensor that falls in the $10^{-7}-10^{-8}$ mol L-1 range. ${ }^{15,19,21,30,31}$ The LOD is comparable with that found with the graphite-poliuretane composite electrode ${ }^{16}$ in the order of $10^{-9} \mathrm{~mol} \mathrm{~L}^{-1}$.

Other components of the pharmaceutical formulation (a natural extract) did not interfere in the measurements as performed.

\section{References}

1. Pungor, E.; Szepesváry, É.; Anal. Chim. Acta 1968, 43, 289.

2. Miller, F. J.; Zittel, H. E.; Anal. Chem. 1963, 35, 1866.

3. Zittel, H. E.; Miller, F. J.; Anal. Chem. 1965, 37, 200.

4. Edmonds, T. E.; Anal. Chim. Acta 1985, 176, 1.

5. Kissinger, P. T.; Heineman, W. R.; Laboratory Techniques in Electroanalytical Chemistry, Marcel Dekker: New York, 1996.

6. Tallman, D. E.; Petersen, S .L.; Electroanalysis 1990, 2, 499.

7. Kalcher, K.; Kauffman, J. M.; Wang, J.; Svancara, I.; Vytras, K.; Neuhold, C.; Yang, Z.; Electroanalysis 1995, 7, 5.

8. Oliveira, A. C., Santos, S. X., Cavalheiro, E. T. G.; Talanta 2008, 74, 1043.

9. Céspedes, F.; Martinez-Fábregas, E; Alegret, S.; Trends Anal. Chem. 1996, 15, 296.

10. Ghica, M. A.; Brett, A. M. O.; Electroanalysis 2005, 17, 313.

11. Reichart, E.; Obendorf, D.; Anal. Chim. Acta 1998, 360, 179.

12. Cook, N. C.; Samman, S.; J. Nutr. Biochem. 1996, 7, 66.
13. Zoulis, N. E.; Efstathiou, C. E.; Anal. Chim. Acta 1996, 320, 255.

14. Kang, J. W.; Lu, X. Q.; Zeng, H. J.; Liu, H. D.; Lu, B.Q.; Anal. Lett. 2002, 35, 677.

15. Hua, J.; He, X.; Liao, F.; Zhu, Q.; Dianhuaxue 2008, 14, 87.

16. Malagutti, A. R.; Zuin, V. G.; Cavalheiro, E. T. G.; Mazo, L. H.; Electroanalysis 2006, 18, 1028.

17. Volikakis, G. J.; Efstathiou, C. E.; Talanta 2000, 51, 775.

18. Zoulis, N. E.; Efstathiou, C. E; Anal. Chim. Acta 1996, 320, 255.

19. Yongxia, Q.; Li, R.; Shen, J.; Huang, S.; Huaxue Chuanganqi 2007, 27, 49.

20. Santos, D. P.; Bergamini, M. F.; Santos, V. A. F. F. M.; Furlan, M.; Zanoni, M. V. B.; Anal. Lett. 2007, 40, 3430.

21. He, J.; Yang, Y.; Yang, X.; Liu, Y.; Liu, Z.; Shen, G.; Yu, R.; Sens. Actuators, B 2006, 114, 94.

22. Franzoi, A. C.; Spinelli, A.; Vieira, I. C.; J. Pharm. Biomed. Anal. 2008, 47, 973.

23. Farmacopéia Brasileira, 4ª ed., Atheneu Editora São Paulo LTDA: São Paulo, 1988, Vol. II.

24. Cunnif, P., ed. In Official Methods of Analysis of AOAC International, vol. 1, Arlington: AOAC International, 1995, p. 29.

25. Bard, A. J.; Faulkner, L. R.; Electrochemical Methods: Fundamentals and applications, $2^{\text {nd }}$ ed., Wiley \& Sons: New York, 1980.

26. Brown, E. R.; Large, R. F.; Physical Methods of Chemistry, vol.1; Wiley Interscience: New York, 1971, pp.425-530.

27. Zeng, B.; Wei, S.; Xiao, F.; Zhao, F.; Sens. Actuators, B 2006, $115,240$.

28. van Acker, S. A. B. E.; de Groot, M. J.; van den Berg, D. J.; Tromp, M. N. J. L.; Donne-op den Kelder, G.; van der Vijgh, W. J. F.; Bast, A.; Chem. Res. Toxicol. 1996, 9, 1305.

29. Bao, X.; Zhu, Z.; Li, N.; Chen, J.; Talanta 2001, 54, 591.

30. Zhang, Y.; Chen, W.; Wu, P.; Lin, X.; Huaxue Yanjiu 2005, 16, 84.

31. Sun, Y.; Lan, H.; Huaxue Fence 2003, 39, 579.

Received: April 3, 2008

Web Release Date: October 8, 2008

FAPESP helped in meeting the publication costs of this article. 